\title{
Pulmonary gas exchange during facemask ventilation immediately after birth
}

\author{
C Palme-Kilander, R Tunell
}

\begin{abstract}
The rate of carbon dioxide production $\left(\mathrm{VCO}_{2}\right)$, heart rate, and oxygen saturation were recorded during resuscitation in $\mathbf{3 0}$ newborn infants. Twenty eight infants were ventilated through a facemask only and two were intubated after initial facemask ventilation. Five neonates were born at full term, eight had a gestational age of 32-36 weeks, and 17 of 27-31 weeks. Towards the end of the five minute study period, the $\mathrm{VCO}_{2}$ in ventilated infants, born after 32 weeks or more, was not different from that of spontaneously breathing infants. Neonates with a gestational age of 27-31 weeks showed a low $\mathrm{VCO}_{2}$, particularly when no reflex response from the baby was recorded, with a significant increase if a reflex response was elicited. Ventilation was found to be satisfactory if the heart rate increased to 130 beats/min or more within 5-15 seconds or if the oxygen saturation, measured in the right hand, was $70 \%$ or more.
\end{abstract}

(Arch Dis Child 1993;68:11-6)

In Sweden, $80 \%$ of newborn infants who need assisted ventilation during resuscitation are satisfactorily ventilated with a bag and facemask. ${ }^{1}$ In other countries ventilation through an endotracheal tube is used and recommended more often than mask ventilation. ${ }^{23}$

An evaluation of the effect of ventilation through a facemask, in which tidal volumes were compared with those achieved during ventilation through an endotracheal tube, showed that facemask ventilation was less efficient. ${ }^{4}$ This finding was ascribed to the use of a resuscitator with too small a bag volume so that relatively low pressures were transmitted to the facemask. Hence, this did not really constitute an adequate comparison of the mask with tube ventilation. Thus no satisfactory assessment of the effect of ventilation through a facemask has yet been performed.

The aim of the present study was to determine the effect of ventilation through a facemask in the resuscitation of term and preterm neonates. This was done by investigating the pulmonary gas exchange during assisted ventilation, and by evaluating clinical indices, such as heart rate and peripherally recorded oxygen saturation.

\section{Patients and methods}

METHODS

The equipment for recording pulmonary gas exchange, heart rate, and oxygen saturation has been described earlier. ${ }^{5}$ An open system was used to study pulmonary gas exchange (see first paper $^{6}$ ). The infants were ventilated with, or inhaled, a carbon dioxide free gas mixture of $50 \%$ oxygen in nitrogen or air. All infants in this study were given $50 \%$ oxygen in nitrogen. A $500 \mathrm{ml}$ infant resuscitator (Laerdal Infant Resuscitator) was connected to the incoming gas tubing. Inspiratory times of $0.5-2$ seconds were used. A $200 \mathrm{ml}$ plastic balloon, which was connected to the incoming gas tubing, served two purposes: (i) to prevent pressure changes in the incoming gas tubings during spontaneous breathing and (ii) to adjust the flow of the incoming gas to balance gas supply against gas collection. The method has been shown to work during both spontaneous breathing ${ }^{6}$ and assisted ventilation. ${ }^{5}$

Gas was removed from the baby through an opening in the facemask. The exhaled, diluted, and cooled gas was collected in 20 bags during periods of 15 seconds' duration and analysed for volume and gas fractions after the five minute study period. Evaluation of the equipment has shown that the mean (SD) detection rate for carbon dioxide injected into the gas sampling system was $93(6) \%$. The system was sufficiently sensitive to be able to detect a rate of carbon dioxide production $\left.\dot{\mathrm{V}} \mathrm{CO}_{2}\right)$ of $2 \mathrm{ml} / \mathrm{kg} / \mathrm{min}$, so was suitable for use even in very low birthweight infants.

The oesophageal pressure was recorded by a catheter tip pressure transducer that was inserted into the lower third of the oesophagus (Gaeltec No $16 \mathrm{CT} / \mathrm{s}$ ). The insufflation pressure was also recorded (Siemens-Elema pressure transducer No 746). The two pressures, as well as heart rate, oxygen saturation, and time of change in gas collection bags were recorded on a recorder (Siemens-Elema Mingograph No 803).

The presence or absence of a reflex response from the infant during ventilation was judged by the oesophageal pressure curve: a negative pressure, often down to $30 \mathrm{~cm}$ $\mathrm{H}_{2} \mathrm{O}$, indicated a gasp; a positive pressure, often continuing after the end of the insufflation, signified an expiratory effort.

Heart rate was recorded by the use of pregelled silver chloride electrodes (Medicotest-N-OQ-25) that were applied to the chest and connected to the pulse oximeter. Oxygen saturation was recoded with a Nellcor 200 transmission pulse oximeter, which was applied to the right hand when this could easily be done, or to a foot when application on the right hand was not feasible. 
Details of the ventilated infants

\begin{tabular}{|c|c|c|c|c|c|c|c|}
\hline $\begin{array}{l}\text { Infant } \\
\text { no }\end{array}$ & $\begin{array}{l}\text { Gestational } \\
\text { age } \\
\text { (weeks) }\end{array}$ & $\begin{array}{l}\text { Birth weight } \\
(g)\end{array}$ & $\begin{array}{l}\text { Umbilical } \\
\text { artery } p H\end{array}$ & Comments & $\begin{array}{l}\text { Apgar } \\
\text { score } \\
(1-5-10 \text { mins })\end{array}$ & $\begin{array}{l}\text { Time } \\
\text { until } \\
\text { cry }\end{array}$ & Subsequent course \\
\hline 1 & 28 & 870 & $7 \cdot 14$ & $\begin{array}{l}5 \text { days PROM. Amnionitis. } \\
\text { Caesarean section for decelerations, } \\
\text { bradycardia } 15 \mathrm{~min}\end{array}$ & $1-7-7$ & $5^{\prime} 30^{\prime \prime}$ & Died of IVH before 24 hours \\
\hline 2 & 30 & 1500 & & Vaginal vertex. Forceps for bradycardia & $1-5-7$ & $4^{\prime} 30^{\prime \prime}$ & $\begin{array}{l}\text { Slight wet lung. } \\
\text { Healthy at discharge }\end{array}$ \\
\hline 3 & 33 & 2080 & & $\begin{array}{l}\text { Vaginal vertex with vaginal bleeding. } \\
\text { Bradycardia for } 10 \text { minutes }\end{array}$ & $2-7-8$ & $4^{\prime} 15^{\prime \prime}$ & $\begin{array}{l}\text { Slight wet lung. } \\
\text { Healthy at discharge }\end{array}$ \\
\hline 4 & 27 & 1250 & $6 \cdot 97$ & Vaginal breech/double foot & $1-3-5$ & $14^{\prime}$ & $\begin{array}{l}\text { Ventilated from age of } 1 \text { hour. } \\
\text { Died of IHV }\end{array}$ \\
\hline 5 & 39 & 3720 & 6.99 & Vaginal breech with dystocia & $3-7-7$ & $1^{\prime}$ & Healthy at discharge \\
\hline 6 & 29 & 1580 & $7 \cdot 24$ & $\begin{array}{l}\text { Caesarean section for amnionitis, } \\
\text { fever, breech }\end{array}$ & $3-7-7$ & $4^{\prime}$ & HMD. Healthy at discharge \\
\hline 7 & 36 & 2860 & $6 \cdot 86$ & $\begin{array}{l}\text { Twin 2. Vaginal delivery. } \\
\text { Shoulder dystocia }\end{array}$ & $3-7-8$ & $2^{\prime} 30^{\prime \prime}$ & Healthy at discharge \\
\hline 8 & 28 & 1240 & & $\begin{array}{l}4 \text { weeks PROM. Abruptio placentae. } \\
\text { Caesarean section for CTG } \\
\text { decelerations }\end{array}$ & $1-7-7$ & $4^{\prime}$ & $\begin{array}{l}\text { Ventilator. Died at } 8 \text { hours } \\
\text { of pulmonary hypoplasia }\end{array}$ \\
\hline 9 & 39 & 2580 & $7 \cdot 04$ & $\begin{array}{l}\text { Asphyxia in vaginal delivery. } \\
\text { Caesarean section }\end{array}$ & $2-8-8$ & $1^{\prime}$ & Healthy at discharge \\
\hline 10 & 28 & 1065 & & $\begin{array}{l}\text { Twin 2. Caesarean section with difficult } \\
\text { extraction }\end{array}$ & $3-7-8$ & $3^{\prime}$ & $\begin{array}{l}\text { Wet lung. CPAP } 6 \text { days. } \\
\text { Healthy at discharge }\end{array}$ \\
\hline 11 & 32 & 2560 & & $\begin{array}{l}\text { IDM. Caesarean section for decelerations, } \\
\text { labour, breech }\end{array}$ & $1-7-8$ & 3'15" & $\begin{array}{l}\text { Wet lung. CPAP } 6 \text { days. } \\
\text { Healthy at discharge }\end{array}$ \\
\hline 12 & 39 & 2780 & $7 \cdot 07$ & Vaginal vertex with dystocia & $1-8-9$ & $45^{\prime \prime}$ & Healthy at discharge \\
\hline 13 & 32 & 2040 & $7 \cdot 04$ & $\begin{array}{l}\text { Toxaemia. Caesarean section for asphyxia } \\
\text { during delivery }\end{array}$ & $1-7-7$ & $3^{\prime} 45^{\prime \prime}$ & Healthy at discharge \\
\hline 14 & 39 & 2880 & $7 \cdot 01$ & $\begin{array}{l}\text { Caesarean section for asphyxia during } \\
\text { vaginal delivery. Heavy meconium staining }\end{array}$ & $1-6-8$ & $5^{\prime} 30^{\prime \prime}$ & Healthy at discharge \\
\hline 15 & 38 & 2770 & $7 \cdot 33$ & $\begin{array}{l}\text { Toxaemia. Induction. Thick meconium. } \\
\text { Caesarean section for signs of asphyxia } \\
\text { during delivery }\end{array}$ & $4-7-9$ & $3^{\prime}$ & Healthy at discharge \\
\hline 16 & 30 & 1400 & & $\begin{array}{l}\text { Severe toxaemia. Caesarean section for high } \\
\text { blood pressure and decelerations. } \\
\text { Labetalol and hydralazine }\end{array}$ & $2-7-8$ & $6^{\prime}$ & Healthy at discharge \\
\hline 17 & 29 & 980 & $7 \cdot 29$ & $\begin{array}{l}\text { Caesarean section for severe toxaemia. } \\
\text { Labetalol }\end{array}$ & $2-7-8$ & $4^{\prime}$ & $\begin{array}{l}\text { Wet lung. CPAP } 3 \text { days. } \\
\text { Healthy at discharge }\end{array}$ \\
\hline 18 & 34 & 2120 & $7 \cdot 25$ & $\begin{array}{l}\text { Caesarean section for severe toxaemia. } \\
\text { Labetalol and hydralazine }\end{array}$ & $1-5-8$ & $5^{\prime} 30^{\prime \prime}$ & Healthy at discharge \\
\hline 19 & 30 & 1300 & & $\begin{array}{l}\text { Severe toxaemia. Caesarean section. } \\
\text { Labetalol }\end{array}$ & $2-5-9$ & $6^{\prime}$ & Healthy at discharge \\
\hline 20 & 29 & 760 & $7 \cdot 34$ & $\begin{array}{l}\text { Caesarean section for IUGR. Decelerations } \\
\text { without labour }\end{array}$ & $3-9-9$ & 3'45" & $\begin{array}{l}\text { Wet lung. CPAP } 3 \text { days. } \\
\text { Healthy at discharge }\end{array}$ \\
\hline 21 & 31 & 1330 & & $\begin{array}{l}\text { Caesarean section for toxaemia. CTG } \\
\text { decelerations. Labetalol }\end{array}$ & $3-8-8$ & $5^{\prime}$ & $\begin{array}{l}\text { CPAP } 3 \text { days for HMD. } \\
\text { Healthy at discharge }\end{array}$ \\
\hline 22 & 35 & 1640 & $7 \cdot 14$ & $\begin{array}{l}\text { Caesarean section for IUGR and toxaemia. } \\
\text { Thick meconium }\end{array}$ & $1-7-8$ & 5 ' & $\begin{array}{l}\text { Parenchymal ICH. At } 1 \text { year: } \\
\text { with minor handicap. No } \\
\text { breathing problem }\end{array}$ \\
\hline 23 & 33 & 1820 & $7 \cdot 31$ & $\begin{array}{l}\text { Caesarean section for severe toxaemia. } \\
\text { Labetalol and diazepam }\end{array}$ & $3-7-8$ & 4'30" & CPAP for HMD \\
\hline 24 & 31 & 1490 & $7 \cdot 23$ & Caesarean section for severe toxaemia & $3-8-8$ & & Healthy at discharge \\
\hline 25 & 28 & 1175 & $7 \cdot 26$ & Vaginal vertex delivery & $3-4-8$ & 6'15" & $\begin{array}{l}\text { Wet lung. CPAP. } \\
\text { Healthy at discharge }\end{array}$ \\
\hline 26 & 27 & 1100 & $7 \cdot 36$ & $\begin{array}{l}\text { Caesarean section for maternal disease } \\
\text { (ulcerative colitis) }\end{array}$ & $2-8-8$ & $5^{\prime} 30^{\prime \prime}$ & $\begin{array}{l}\text { Slight wet lung. } \\
\text { Healthy at discharge }\end{array}$ \\
\hline $27^{\circ}$ & 35 & 2295 & & $\begin{array}{l}\text { Hypertension. PROM. Caesarean section. } \\
\text { Hydralazine }\end{array}$ & $2-8-8$ & $5^{\prime} 15^{\prime \prime}$ & Healthy at discharge \\
\hline 28 & 27 & 908 & $7 \cdot 23$ & Toxaemia. Labetalol & $1-8-10$ & $3^{\prime}$ & $\begin{array}{l}\text { HMD. Ventilator. } \\
\text { Died of BPD at } 4.5 \text { months }\end{array}$ \\
\hline $\begin{array}{l}29 \\
30\end{array}$ & $\begin{array}{l}30 \\
31\end{array}$ & $\begin{array}{l}1770 \\
1600\end{array}$ & $7 \cdot 27$ & $\begin{array}{l}11 \text { weeks PROM. Vaginal vertex } \\
3 \text { weeks PROM. Caesarean section for } \\
\text { uterine contractions. Breech }\end{array}$ & $\begin{array}{l}2-8-8 \\
3-8-9\end{array}$ & $\begin{array}{l}5^{\prime} \\
6^{\prime}\end{array}$ & $\begin{array}{l}\text { Healthy at discharge } \\
\text { Healthy at discharge }\end{array}$ \\
\hline
\end{tabular}

$\mathrm{BPD}=$ bronchopulmonary dysplasia, $\mathrm{CPAP}=$ continuous positive airway pressure, $\mathrm{CTG}=$ cardiotocographic monitoring, $\mathrm{HMD}=\mathrm{hyaline}$ membrane disease, $\mathrm{ICH}=$ intracranial haemorrhage, IDM=infant of diabetic mother, IUGR=intrauterine growth retardation, IVH=intraventricular haemorrhage, $P R O M=$ premature $\mathrm{ICH}=$ intracranial haem
rupture of membranes.

A tape recorder recorded all events, such as cries and other sounds from the baby and from the Apgar timer, and comments on the infant's clinical condition, during the five minute study period.

PATIENTS

All newborn infants born between February 1988 and July 1989 without malformations, and in need of assisted ventilation at birth, were included in the study if at least one of our team was present and had time to prepare the equipment before the infant was born. Assisted ventilation was considered necessary if the infant was apnoeic at 30 seconds after birth and had a heart rate below 100 beats/min.

Thirty neonates with postnatal asphyxia were studied. Details concerning the clinical findings, umbilical artery $\mathrm{pH}$ (performed in 20 to 30 patients), birth weight, and subse- quent course are give in the table. Gestational age was 37 weeks or more in five infants, 32-36 weeks in eight infants, and 27-31 weeks in 17 infants. Twenty of the 30 infants had established regular spontaneous breathing within five minutes after birth, 29 of the 30 within 10 minutes, and all within 15 minutes after birth. The Apgar score at 1 minute after birth was 3 or less in 29 infants and 4 in the remaining neonate. The Apgar score at 10 minutes was 7 or more in 29 infants and 5 in one.

For comparison, $\dot{\mathrm{VCO}}_{2}$ in spontaneously breathing, healthy infants during the first five minutes after birth is also presented. Data concerning these spontaneously breathing infants have been presented elsewhere. ${ }^{6}$ Thirty were full term infants, of whom 15 were delivered vaginally and 15 by elective caesarean section. Twelve preterm infants were studied with a gestational age of 32-36 
weeks. Ten of these 12 were born by caesarean section. One infant with a gestational age of less than 32 weeks was studied during spontaneous breathing. This infant was vaginally delivered after 31 weeks of gestation and had a birth weight of $1470 \mathrm{~g}$.

\section{STATISTICAL METHODS}

For comparison of $\mathrm{VCO}_{2}$ between the different gestational age groups and between spontaneously breathing and ventilated infants, the Mann-Whitney U test was used. For comparisons within groups, the Wilcoxon signed rank test for paired samples was used, and $p$ values were corrected according to Bonferroni when appropriate. The $95 \%$ confidence inter-
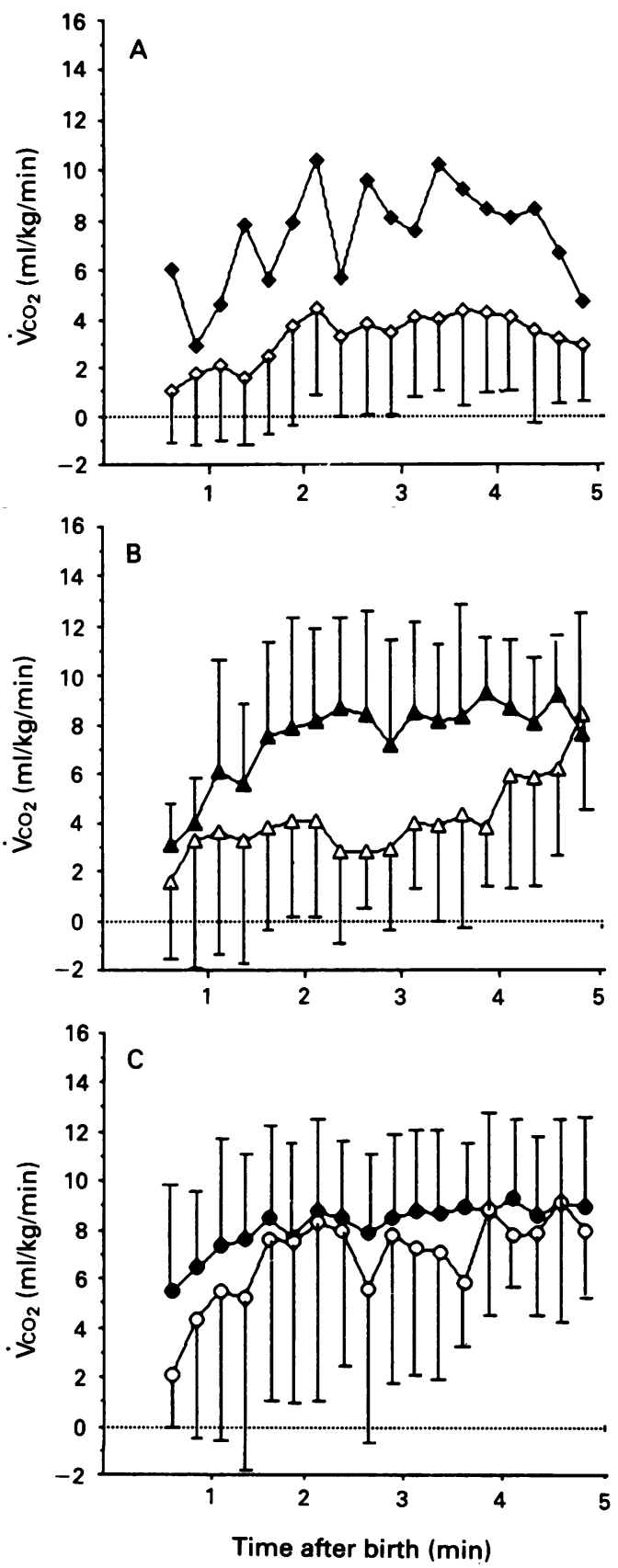

Figure 1 Mean (SD) $\dot{V} \mathrm{CO}_{2}$ during the first five minutes after birth in babies requiring assisted ventilation (open symbols) and those breathing spontaneously (closed symbols). (A) Infants 27-31 weeks: ventilated $(n=17)$ and spontaneously breathing $(n=1)$. (B) Infants 32-36 weeks: ventilated $(n=8)$ and spontaneously breathing $(n=11)$. (C) Term infants: ventilated $(n=5)$ and spontaneously breathing $(n=30)$. vals $(\mathrm{CI})$ and SD were calculated using the mean value for each infant.

The study was approved by the local ethics committee.

\section{Results}

PULMONARY GAS EXCHANGE DURING

VENTILATION

The $\mathrm{VCO}_{2}$ during the first five minutes after birth in the three gestational age groups of neonates is shown in fig $1 \mathrm{~A}-\mathrm{C}$ together with that in healthy, spontaneously breathing neonates. All three groups show wide variations. The gas exchange in the gestational age group 27-31 weeks was generally below $4 \mathrm{mg} / \mathrm{kg} / \mathrm{min}$, with a significant increase $(p<0.05)$ between the first and the fifth minute. For the group 32-36 weeks, the gas exchange was lower than that of spontaneously breathing neonates with the same gestational age during the second $(\mathrm{p}<0.05)$, third $(\mathrm{p}<0.01)$, and fourth $(\mathrm{p}<0.01)$ minutes, but not during the fifth minute after birth. For term infants, the $\mathrm{VCO}_{2}$ is not significantly different from that of spontaneously breathing term infants during the five minute period.

The $\mathrm{VCO}_{2}$ during periods of assisted ventilation is shown in figs 2 and 3 . In periods when no reflex response from the infant was recorded-in the form of a gasp or, less often, an expiratory effort-mean (SD) $\mathrm{VCO}_{2}$ was $2 \cdot 2(1 \cdot 8) \mathrm{ml} / \mathrm{kg} / \mathrm{min}$ in the group with a gestational age of 27-31 weeks (fig 3). Such periods were initially recorded in 13 of the 17 infants. In seven of these very preterm infants, no carbon dioxide was initially detected. In six of the eight infants with a gestational age of 32-36 weeks, such non-reflex response periods were initially recorded, with a mean (SD) $\mathrm{VCO}_{2}$ during non-reflex periods of $2 \cdot 6$ (3.1) $\mathrm{ml} / \mathrm{kg} / \mathrm{min}$. No carbon dioxide was initially detected in three of these six infants. In term infants, such non-reflex response periods were seen in two of the six, with $\mathrm{VCO}_{2}$ values of 1.9 and $2.7 \mathrm{ml} / \mathrm{kg} / \mathrm{min}$, respectively.

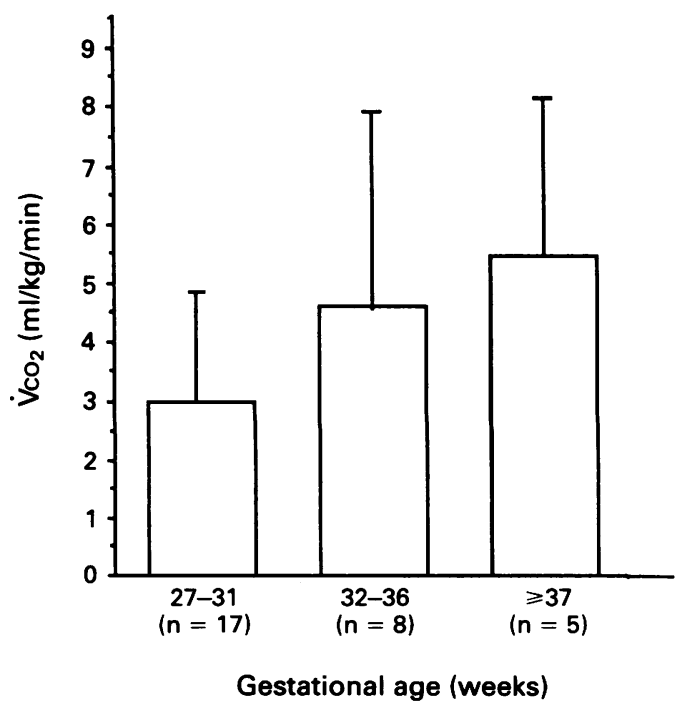

Figure 2 Mean (SD) $\dot{V C O}_{2}$ in all ventilated infants during periods of assisted ventilation. 


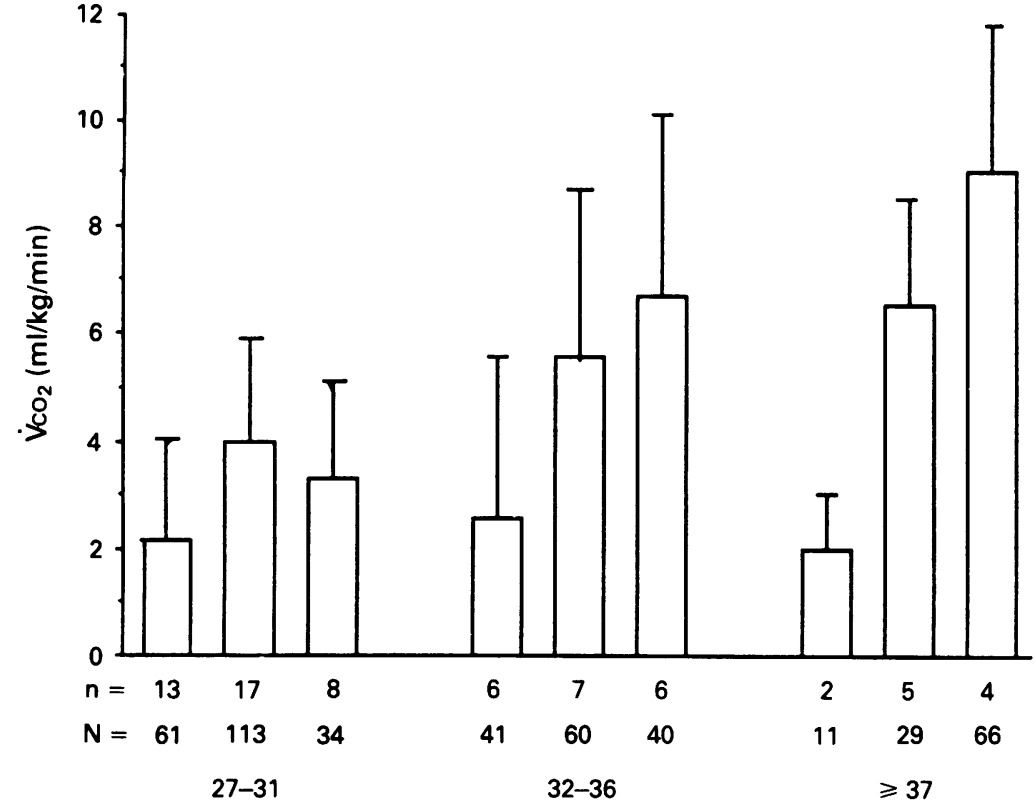

Gestational age (weeks)

Figure 3 Mean (SD) $\dot{V} \mathrm{CO}_{2}$ in three gestational age groups of ventilated infants during periods of assisted ventilation without a reflex response (left), with a reflex response (middle), and during spontaneous breathing after assisted ventilation ( $n=n u m b e r$ of infants, $N=$ total number of 15 second periods with that type of ventilation/breathing, that were studied). $\mathrm{VCO}_{2}$ was significantly higher during ventilation with compared with withou a reflex response in 27-31 weeks infants $(p<0.01)$ and in 32-36 weeks infants $(p<0.05)$.

When a reflex response was elicited from the infant, the $\mathrm{VCO}_{2}$ increased significantly in the most preterm group $(p<0 \cdot 01)$ to $4 \cdot 0(1 \cdot 8)$ $\mathrm{ml} / \mathrm{kg} / \mathrm{min}$. In the 32-36 week group, a significant increase in $\mathrm{VCO}_{2}$ to $5 \cdot 6(2.9) \mathrm{ml} / \mathrm{kg} / \mathrm{min}$ was also recorded $(\mathrm{p}<0.05)$. In the five term infants, $\mathrm{VCO}_{2}$ during such periods was $6 \cdot 4(2 \cdot 0)$ $\mathrm{ml} / \mathrm{kg} / \mathrm{min}$.

In 12 of the 30 infants with postnatal asphyxia (nine very preterm, two intermediate, and one full term infant) insufflation pressure was increased to a mean of $65 \mathrm{~cm} \mathrm{H}_{2} \mathrm{O}$ (range $50-85 \mathrm{~cm} \mathrm{H}_{2} \mathrm{O}$ ). In 10 infants (six very preterm, three intermediate, and one full term infant) insufflation pressure of $25-30 \mathrm{~cm} \mathrm{H}_{2} \mathrm{O}$ resulted in a satisfactory clinical response to ventilation, and in seven of the 30 infants an initial insufflation pressure of $60 \mathrm{~cm} \mathrm{H}_{2} \mathrm{O}$ was used. Two infants were ventilated through an endotracheal tube because of their unsatisfactory clinical response to ventilation. In one of these two (No 18, table), the first period of tube ventilation showed no carbon dioxide produced. During the second and third 15 second periods of tube ventilation, a reflex gasp was recorded, and the $\mathrm{VCO}_{2}$ amounted to 2.0 and $4.7 \mathrm{ml} / \mathrm{kg} / \mathrm{min}$, respectively, with a gradual increase in heart rate and oxygen saturation during the next minute. After 5 minutes and 30 seconds, spontaneous breathing became satisfactory.

The second infant (No 4, table), delivered vaginally with severe asphyxia, responded immediately with a $\dot{\mathrm{V}} \mathrm{CO}_{2}$ of $2.7 \mathrm{ml} / \mathrm{kg} / \mathrm{min}$ as soon as ventilation through the tube was initiated.
PULMONARY GAS EXCHANGE AFTER

ESTABLISHMENT OF SPONTANEOUS BREATHING

In 18 of the 20 infants who established regular spontaneous breathing within five minutes after birth, the $\dot{V C O}_{2}$ during spontaneous breathing was recorded. A mean (SD) $\dot{\mathrm{VCO}}_{2}$ of $3.3(1.5) \mathrm{ml} / \mathrm{kg} / \mathrm{min}$ was found in the very preterm group. Five of these preterm infants were studied during 12 periods of regular crying. Gas exchange during such periods amounted to a mean (SD) $\mathrm{VCO}_{2}$ of $5 \cdot 2(1 \cdot 6)$ $\mathrm{ml} / \mathrm{kg} / \mathrm{min}$. Five very preterm babies, including four of the above, were also studied during periods of calm breathing. Their mean $\mathrm{VCO}_{2}$ was then $1 \cdot 6(3 \cdot 1) \mathrm{ml} / \mathrm{kg} / \mathrm{min}$.

In four of the very preterm infants ventilation was stopped because the infant cried or breathed regularly, but as soon as assisted ventilation was stopped, spontaneous breathing ceased and $\mathrm{VCO}_{2}$ fell to values below $2 \mathrm{ml} / \mathrm{kg} / \mathrm{min}$. Immediately after resumption of ventilation regular breathing was initiated and a rising $\mathrm{VCO}_{2}$ was again recorded. The mean (SD) $\mathrm{VCO}_{2}$ during spontaneous breathing was $6 \cdot 7(3.2) \mathrm{ml} / \mathrm{kg} / \mathrm{min}$ in the group of $32-36$ weeks' gestation and $9 \cdot 1(2 \cdot 7) \mathrm{ml} / \mathrm{kg} / \mathrm{min}$ in the full term neonates.

HEART RATE IN RELATION TO GAS EXCHANGE The $95 \%$ CI for heart rate in relation to $\mathrm{VCO}_{2}$ during periods of assisted ventilation is shown in fig 4. During periods of assisted ventilation with a $\mathrm{VCO}_{2}$ of less than $2 \mathrm{ml} / \mathrm{kg} / \mathrm{min}$ some degree of increase in heart rate often occurred

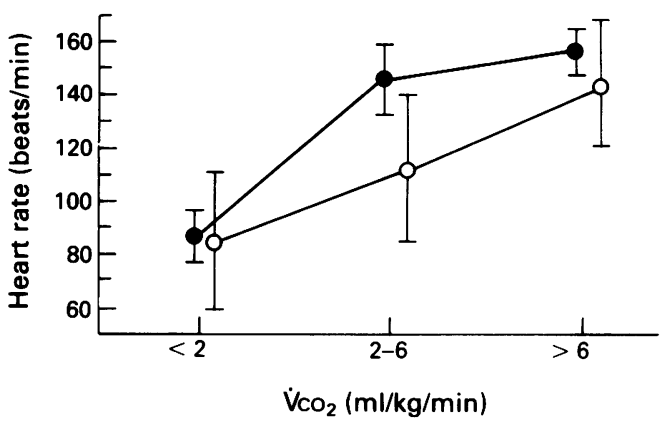

Figure $495 \%$ CI for heart rate in relation to $\dot{V C O}_{2}$, recorded during the same 15 second period, in infants whose mothers were not (closed circles) or who were (open circles) treated with labetalol before delivery.

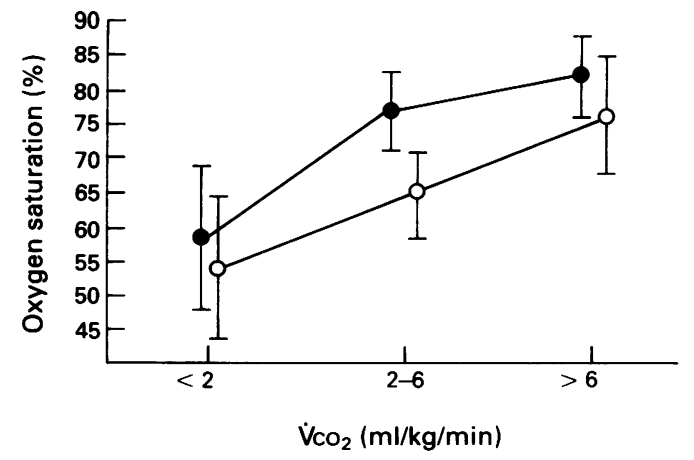

Figure $595 \%$ CI for oxygen saturation, recorded in the right hand (closed circles) or in a foot (open circles) in relation to $\dot{V} \mathrm{CO}_{2}$, recorded 30 seconds earlier. 
to a mean of $87(95 \%$ CI 77 to 96$)$ beats $/ \mathrm{min}$. An immediate rise in heart rate to 132-159 (mean 145) beats/min was recorded in connection with a $\mathrm{VCO}_{2}$ of $2-6 \mathrm{ml} / \mathrm{kg} / \mathrm{min}$ for all infants whose mothers were not treated with labetalol. Within the next 15 second period, all of these infants had a heart rate above 140 beats/min. The same infants had a heart rate of 148-164 (mean 156) beats/min when $\mathrm{VCO}_{2}$ increased to $6 \mathrm{ml} / \mathrm{kg} / \mathrm{min}$ or more. The corresponding values for infants of labetalol treated mothers can be seen in fig 4 . In one of these, the heart rate remained below 100 beats $/ \mathrm{min}$ during 45 seconds, despite a $\mathrm{VCO}_{2}$ of 3-6 $\mathrm{ml} / \mathrm{kg} / \mathrm{min}$. In the other six infants, the heart rate rose to 130 beats/min within the next 15 second period after a $\dot{\mathrm{VCO}}_{2}$ of at least 2 $\mathrm{ml} / \mathrm{kg} / \mathrm{min}$ was recorded.

A transient increase in heart rate, to a mean of 100 beats/min despite no detectable carbon dioxide production, was recorded in eight infants. The mean birth weight of these eight was $1530 \mathrm{~g}$.

PERIPHERAL OXYGEN SATURATION IN RELATION TO GAS EXCHANGE

Oxygen saturation was recorded in the right hand of 12 infants and in seven infants in a foot when the recording from the right hand was unsuccessful. The $95 \% \mathrm{CI}$ for oxygen saturation in relation to $\mathrm{VCO}_{2} 30$ seconds earlier is shown in fig 5 . Recordings in the right hand showed oxygen saturation values below $70 \%$ when $\mathrm{VCO}_{2}$ was less than $2 \mathrm{ml} / \mathrm{kg} / \mathrm{min}, 71-82$ (mean 76 ) $\%$ when $\mathrm{VCO}_{2}$ was $2-6 \mathrm{ml} / \mathrm{kg} / \mathrm{min}$, and $76-87$ (mean 81 ) \% when a $\mathrm{VCO}_{2}$ of $6 \mathrm{ml} / \mathrm{kg} / \mathrm{min}$ or more was recorded. Recordings from a foot generally showed lower values.

\section{Discussion}

Our knowledge about the appropriate $\mathrm{VCO}_{2}$ during the first minutes after birth in very preterm infants is deficient. The only infant with a gestational age below 32 weeks, who was studied during spontaneous breathing only, had a $\mathrm{VCO}_{2}$ between 6 and $10 \mathrm{ml} / \mathrm{kg} / \mathrm{min}$ (fig 1A) during vigorous crying. The five infants who were studied during regular crying after a period of assisted ventilation achieved a $\mathrm{VCO}_{2}$ of $5 \cdot 2(1 \cdot 6) \mathrm{ml} / \mathrm{kg} / \mathrm{min}$.

In spontaneously breathing full term infants, $\dot{\mathrm{V}} \mathrm{CO}_{2}$ and the rate of oxygen consumption $\left(\mathrm{Vo}_{2}\right)$ above $7 \mathrm{ml} / \mathrm{kg} / \mathrm{min}$ have proved to be necessary to avoid persistent hypoxaemia. ${ }^{7}$ During assisted ventilation a slightly lower $\mathrm{VCO}_{2}$ is probably sufficient as the work of breathing does not have to be accounted for. A $\mathrm{VCO}_{2}$ of $5-6 \mathrm{ml} / \mathrm{kg} / \mathrm{min}$ may arbitrarily be used as a minimum requirement immediately after birth in full term infants who are being ventilated. Infants of 32-36 weeks' gestation have been shown to have a $\mathrm{VCO}_{2}$ that does not differ from that of full term infants. ${ }^{6}$

As two thirds of the mask ventilated infants established regular spontaneous breathing within five minutes and 29 of 30 infants within 10 minutes after birth, ventilation must have been efficient. These findings are consis- tent with-and slightly better than-the results of a recent survey of postnatal asphyxia from the whole of Sweden during one year. ${ }^{1}$ Despite this, $\mathrm{VCO}_{2}$ was generally low in preterm infants when no reflex response from the baby was recorded.

The possibility that $\mathrm{VCO}_{2}$ was not adequately measured must be considered here. Tests of the equipment that we used have shown that $93 \%$ of carbon dioxide injected into the gas sampling system is detected. Undetected but existing carbon dioxide production with a $\mathrm{VCO}_{2}$ of approximately $1 \mathrm{ml} / \mathrm{kg} / \mathrm{min}$ can thus be excluded.

When the insufflations are performed through a facemask, the possibility that the pressure is not transmitted through the larynx to the lower airways because of laryngeal obstruction must also be considered. Some authors recommended that the anterior aspect of the neck should be examined for laryngeal filling. ${ }^{8}$ This procedure was also used in the present study. In one of the two tube ventilated infants the ventilation resulted in an immediate rise in $\mathrm{VCO}_{2}$ as soon as ventilation through the endotracheal tube was started, which indicates that this may be the case in some infants. The other infant, however, did not respond by a rise in $\mathrm{VCO}_{2}$, heart rate, or oxygen saturation until reflex gasps were elicited. This fact together with the results of other studies, where tidal volumes in very preterm infants as compared with full term infants remained low during assisted ventilation through an endotracheal tube, ${ }^{9}$ indicate that assisted ventilation immediately after birth of very preterm infants is often unsatisfactory.

The finding that gas exchange during ventilation is lower without than with a reflex response from the baby is consistent with studies, in which full term ${ }^{10}$ and preterm 9 infants who were ventilated through an endotracheal tube acquired a functional residual capacity more rapidly when a reflex response from the infant was elicited.

Another study compared the effect of assisted ventilation through an endotracheal tube with ventilation through a facemask. ${ }^{4}$ They found that facemask ventilation was unsatisfactory because the resuscitating bag used in connection with mask ventilation was too small, but they also noted a shorter time until the first spontaneous gasp in mask ventilated than in tube ventilated infants. This was explained by a delay in the spontaneous gasp caused by the intubation itself. In summary it may therefore be said that the effect of ventilation is due largely to the initiation of spontaneous reflex activity in the baby.

The possibility that the pressures used for assisted ventilation through the facemask were too low must be considered. The median insufflation pressure during periods with $\mathrm{VCO}_{2}$ below $2 \mathrm{ml} / \mathrm{kg} / \mathrm{min}$ was $35 \mathrm{~cm} \mathrm{H}_{2} \mathrm{O}$ (range 25-80 $\mathrm{cm} \mathrm{H}_{2} \mathrm{O}$ ). When no clinical response was evident the insufflation time was prolonged from $0 \cdot 7-1$ second initially to 2 seconds. These procedures are in agreement with the inspiratory pressures (mean inspira- 
tory pressure $52 \mathrm{~cm} \mathrm{H}_{2} \mathrm{O}$, range 28-105) recorded in spontaneously breathing infants, ${ }^{11}$ and in agreement with insufflation pressures of 35-67 cm $\mathrm{H}_{2} \mathrm{O}$, median $49 \mathrm{~cm}$, used in intubated asphyxiated neonates. ${ }^{12}$ With an insufflation time as long as 2 seconds and using a resuscitating bag with a big volume, a high insufflation pressure would have been risky and not ethically justified.

The low $\mathrm{VCO}_{2}$, recorded in very preterm infants, probably has a complex explanationdeficient aeration due to residual lung fluid, ${ }^{13}$ very low tone, leading to less active and less frequent crying, and possibly deficient perfusion of the lungs, which may also be influenced by spontaneous breathing movements.

In the resuscitation of newborn infants it is widely accepted that if the heart rate rises to above $80-100$ beats $/ \mathrm{min}$ the ventilation is satisfactory. ${ }^{8} 14$ In the present study, a transient increase in heart rate to 100 beats/min without a measurable gas exchange was recorded in eight of the 30 infants. This may be explained by an effect mediated through pulmonary stretch receptors. As soon as the $\mathrm{VCO}_{2}$ rose above $2 \mathrm{ml} / \mathrm{kg} / \mathrm{min}$ - which is a very low value-the heart rate rapidly increased to 130 beats/min or more, and to $140 \mathrm{beats} / \mathrm{min}$ within the subsequent $15 \mathrm{sec}$ ond period. In infants whose mothers had received $\beta$ blocking agents, lower heart rates were recorded.

The peripherally measured oxygen saturation in relation to $\mathrm{VCO}_{2}$ showed that oxygen saturation rises within $30-45$ seconds and is a reliable sign of effective ventilation, provided the probe is attached preductally to the right hand. This is consistent with other studies, where right to left shunting through the ductus arteriosus persists for several minutes after birth, ${ }^{15} 16$ leading to a high oxygen saturation preductally but a low oxygen saturation or oxygen tension when measured postductally. Measurements of oxygen saturation will hopefully become even more rapid and reliable if reflection pulse oximetry comes into clinical use. ${ }^{17}$

In summary, we found a very low $\mathrm{VCO}_{2}$ in very preterm infants who needed assisted ventilation at birth until reflex response to ventilation could be elicited. During spontaneous breathing after the end of ventilation, $\mathrm{VCO}_{2}$ in very preterm infants was low during calm breathing and increased during periods of cry- ing. Towards the end of the five minute study period, $\mathrm{VCO}_{2}$ in ventilated infants, born after 32 weeks' gestation or more, was not different from the $\mathrm{VCO}_{2}$ in spontaneously breathing infants. We also found that the effect of ventilation can be considered satisfactory if the heart rate rises to 130 beats/min or more within a few seconds and/or if the oxygen saturation, measured in the right hand, amounts to $70 \%$ or more.

This study was supported by grants from the Laerdal Foundation for Acute Medicine, Stavanger, Norway, from Samaaariten Foundation, Stockholm, Sweden, from Crown Princess Lovisa's Association for Child Care, Stockholm Sweden, and from Karolinska Institute, Stockholm, Sweden.

1 Palme-Kilander C. Methods of resuscitation in low Apgar score newborn infants-a national survey. Acta Paediat Scand (in press).

2 Gee V. Perinatal statistics in Western Australia. Fifth Annual Report of the Western Australian Midwive's Notification System. Perth, 1987.

3 Roberton C. Resuscitation. In: Harvey D, Cooke R, Levitt $\mathrm{G}$, eds. The baby under $1000 \mathrm{~g}$. London: Wright, 1989:50-64.

4 Milner AD, Vyas H, Hopkin IE. Efficacy of facemask resuscitation at birth. $B M \mathcal{F} 1984 ; 289: 1^{`} 563-5$

5 Palme-Kilander C, Tunell R. Equipment for recording pulmonary gas exchange immediately after birth during puntaneous breathing and assisted ventilation. Med Biol Eng Comput (in preathing

6 Palme-Kilander C, Tunell R, Chiwei Y. Pulmonary gas exchange immediately after birth in spontaneously exchange immediately after birth in spon

7 Tunell R, Copher D, Persson B. The pulmonary gas exchange and blood gas changes in connection with birth n: Stetson JB, Swyer PR, eds. Current concepts of neonatal intensive care. St Louis: Warren Green, 1974;89-106.

8 Tyson J, Silverman W, Reisch J. Immediate care of the newborn infant. In: Chalmers I, ed. Effective care in pregnancy and childbirth. Oxford: Oxford University Press, 1989:1303-4

9 Hoskyns EW, Milner AD, Boon AW, Vyas H, Hopkin IE Endotracheal resuscitation of preterm infants at birth. Arch Dis Child 1987;62:663-6.

10 Boon AW, Milner AD, Hopkin IE. Lung expansion, tida exchange, and formation of the functional residual capac ity during resuscitation of asphyxiated neonates. 7 Pediatr 1979;95:1032-6.

11 Vyas H, Field D, Milner AD, Hopkin IE. Determinants of the first inspiratory volume and functional residual capacity at birth. Pediatr Pulmonol 1986;2:189-93.

12 Upton CJ, Milner AD. Endotracheal resuscitation of neonates using a rebreathing bag. Arch Dis Child 1991, 66:39-42.

13 Bland RD. Dynamics of pulmonary water before and after birth. Acta Paediatr Scand 1983;suppl305:12-20.

14 Milner AD. Resuscitation of the newborn. Arch Dis Child 1991;66:66-9.

15 Engström L, Karlberg P, Rooth G, Tunell R. The onset of respiration: a study of respiration and changes in blood gases respiration: a study of respiration and changes in blood gases and acid-base balance. New
of Crippled Children, 1966 .

16 Meier-Stauss P, Bucher HU, Hurliman R, König V, Huch $R$. Pulse oximetry used for documenting oxygen saturation and right-to-left shunting immediately after birth Eur f Pediatr 1990;149:851-5.

17 Ewald U, Heltved F. Clinical experience with reflection pulse oximetry in newborn intensive care. Noordwijkerhut, The Netherlands: Hoboken Congress Organization, Erasmus 